\title{
From State Terrorism to State Errorism: Post-Pinochet Chile's Long Search for Truth and Justice
}

\author{
Marivic Wyndham and Peter Read
}

\begin{abstract}
Patio 29 lies in the northern sector of Santiago's General Cemetery. To the naked eye, it is a grim unweeded field of some twelve hundred rusted tin crosses. But to the families of the 1,197 detained-disappeared during Augusto Pinochet's brutal dictatorship, Patio 29 is both a site of horror and a site of hope. Its story begins in SeptemberDecember 1973 when 320 early victims of the repression were brought there in makeshift wooden crates that held as many as three bodies each, and buried in unmarked graves. A few years later, two hundred of those graves were exhumed by the military, and the remains presumably cremated. For another decade, the mass grave remained silent, yielding few of its secrets to the families' demands to know: Where are they? Today, nineteen years into the so-called transition to democracy, Patio 29-the most important single finding in relation to Chile's detained-disappeared-still refuses to reveal the identities of those victims, pressing upon the government of Michelle Bachelet a new question: Who are they? First state terror, now state error have conspired to make Patio 29 one of Chile's principal horror-cum-hopescapes.
\end{abstract}

Key words: State violence, identification of bodies, trauma after state violence, reconciliation, historical representation

On the morning of September 11 of 1973, Chilean Air Force HawkerHunter fighters bombed La Moneda, the presidential palace in the heart of

The Public Historian, Vol. 32, No. 1, pp. 31-44 (February 2010). ISSN: 0272-3433, electronic ISSN 1533-8576.

(C) 2010 by The Regents of the University of California and the

National Council on Public History. All rights reserved.

Please direct all requests for permission to photocopy or reproduce article content through the

University of California Press's Rights and Permissions Web site: www.ucpressjournals.com/reprintInfo.asp. DOI: 10/1525/tph.2010.31.4.31. 
Santiago. Within hours, Salvador Allende, Chile's democratically elected socialist president, lay dead, and a military junta presided over by General Augusto Pinochet assumed power. It dissolved the congress and eliminated the constitution. A brutal political repression followed, resulting in political assassinations and "disappearances," the imprisonment or exile of thousands of Chileans, and the wholesale use of torture. The 1973 coup d'état was the culmination of a process of political polarization between the haves and the havenots, between Left and Right, which left Chilean society deeply divided. Some considered it an unacceptable interruption of democratic rule; others saw it as a necessary move to prevent an impending civil war. ${ }^{1} \mathrm{Few}$ could imagine what was to follow. Historians of Chile have been debating its meaning ever since. $^{2}$

Having thwarted the democratic path to socialism, the military junta vowed to eliminate the "Marxist cancer." They called their crusade "an internal war," and branded the Left "the enemy from within." They imposed a state of siege, with a dusk-to-dawn curfew, and public gatherings of more than three individuals strictly forbidden. Anyone caught violating these orders would be - and many were - shot on sight.

The persecution of so-called suspicious elements began in earnest from the first. Massive, often random, and apparently senseless, many a personal vendetta was settled in those early weeks and months. Neighbor denounced neighbor, sometimes prompted by personal rather than political animosities. Landlords pointed the finger at particular workers based on grievances over old industrial disputes. ${ }^{3}$ Most of the hierarchy of the Socialist and Commu-

1. Jose Zalaquett, Introduction to the English Edition, Report of the Chilean National Commission on Truth and Reconciliation. Truth Commissions Digital Collection: Reports: Chile. http://www.usip.org/library/tc/doc/reports/chile/chile. Accessed August 2, 2008. p. 2.

2. After the National Commission for Truth and Reconciliation Report (Rettig Report) in 1991, and the National Commission on Political Imprisonment and Torture Report (Valech Report) of 2004-05, many early commentaries on the coup and its aftermath, mainly from writers of the Left, focused on the psychological violence of people associated with the coup, including survivors of torture and families of the disappeared. As the critical distance from the trauma has increased, theorists of memory and post-traumatic stress have investigated post-Pinochet Chile in terms of what is remembered, recorded, forgotten, obscured, or silenced in terms of public and private memory. Monica Echeverría and Carmen Castillo, Santiago a Paris: El Vuelo de la Memoria (Santiago: LOM Ediciones, 2002); Maria Emilia Tijoux, Memorias en Busca de Historia. Mas Allá de los Usos Políticos de la Memoria (Actuel Marx Intervenciones, No. 6, Primer Semestre 2008); Steve J. Stern, The Memory Box of Pinochet's Chile (Vols. 1 and 2) (Durham, NC: Duke University Press, 2006); Peter Read and Marivic Wyndham, "Putting Site Back into Trauma Studies: A Study of Five Detention and Torture Centres in Santiago, Chile," Life Writing 5, no. 1, (April 2008): 79-96. Interesting attempts have been made to locate the coup in the context of Chilean state violence and its postdictatorship resolution. Radical History Review, Truth Commissions: State Terror, History, and Memory, 97 (Winter 2007). Scholars of state violence, particularly in Latin America, have contextualized the Pinochet repression in terms of analogies with Guatemala, Argentina, South Africa, Palestine, Israel, etc. Mieke Bal, Jonathan Crewe, and Leo Spitzer (eds.), Acts of Memory: Cultural Recall in the Present (Lebanon, NH: University Press of New England, 1999). See also Javiera Bustamente and Stephan Ruderes, Patio 29: Tras la Cruz de Fierro (Santiago: Ocholibros, 2009).

3. Esteban Larrain, Patio 29: Historias de Silencio (Documentary). Fondo de Desarrollo de las Artes y la Cultura, Ministerio de Educación, Chile. Fundación Ford. 1998. 
nist parties went underground or sought asylum in foreign embassies, but the rank-and-file-composed mainly of students and laborers-remained an easy target. In the first weeks alone, there were some fifty thousand detentions across the country. ${ }^{4}$ Victims of the repression included many professionals — doctors, lawyers, university professors, journalists. Both cities and the countryside felt the weight of the violence. Santiago suffered the greatest casualties. Hundreds of dead were left to rot in the streets; over eighty bodies were seen floating in the waters of Santiago's Rio Mapocho in the first days of the coup. ${ }^{5}$ Military operations in rural areas, such as the Caravan of Death, also left scores of dead in their wake. ${ }^{6}$ The carnage of the early periodSeptember-December 1973 - accounts for over half the total number of five thousand who were disappeared and executed in the seventeen-year period of the dictatorship. ${ }^{7}$

In Santiago, two major sports stadiums-Estadio Nacional and Estadio Chile-were converted precipitately into mass concentration, torture, and extermination camps. ${ }^{8}$ Their existence was public knowledge, but not the identities of their hostages. The constant movement of the prisoners in and out of the stadiums - and into other makeshift detention centers-kept the families in a constant state of uncertainty. Almost invariably, the authorities denied all knowledge, and often threatened the mother, the wife, or the daughter with detention if she persisted in her search.

With no recourse to the judiciary, which like the press, became largely a willing puppet of the Junta, ${ }^{9}$ families of the detained-disappeared turned to each other for support. In late 1974, they made common purpose and formed the Santiago Branch of the Group of Families of Detained-Disappeared. Composed almost wholly of women, it became the most powerful_ and visiblehuman rights organization to develop during the dictatorship, and remains so. The women staged a series of peaceful demonstrations, such as hunger strikes and street protests, in order to attract public attention. Carrying photographs of their missing relatives, they decided to break what they called "the circle of silence" surrounding the detained-disappeared. Banner after banner demanded to know: Where are they? With public gatherings strictly forbidden, the women were exposing themselves to great danger. ${ }^{10}$

Almost from the start, the Catholic Church became a staunch ally: leading a coalition of churches and establishing the Committee for Peace, which in 1976 became the Vicariate of Solidarity of the Catholic Archdiocese of San-

4. Mark Ensalaco, Chile Bajo Pinochet: La Recuperación de la Verdad (Alianza Editorial Madrid, 2002), 71-72.

5. Larrain, Patio 29.

6. Patricia Verdugo, Los Zarpazos del Puma: La Caravana de la Muerte (Santiago: Ediciones Chile América CESOC, 1989).

7. Elias Padilla Ballesteros, La Memoria y el Olvido-Detenidos Desaparecidos en Chile, http://www.nuncamas.org/investig/lamemolv/memolv00.htm. Accessed October 15, 2007.

8. Ensalaco, Chile Bajo Pinochet, 71-73.

9. Zalaquett, Introduction, 3.

10. Larrain, Patio 29. 
tiago. These successive organizations offered critical moral and legal support to the growing numbers of victims of the repression and to their families. They carefully documented every case of a disappeared, and published numerous reports on the general human rights situation in Chile. ${ }^{11}$ Led by Cardinal Raul Silva Enriquez, the Vicariate posed a formidable challenge to the military authorities, which sought to close down the organization on several occasions. ${ }^{12}$

Meanwhile, the search for the detained-disappeared continued. Within days of the coup, word that the morgue was already overwhelmed with hundreds of unidentified bodies led many families to confront the macabre scene of piles and piles of bodies in advanced stages of decomposition stacked up in corridors and offices. Most were naked and bullet-ridden. ${ }^{13}$ When the daughter of a missing farmer from Paine surveyed the scene, she was horrified, but would not leave until she had satisfied herself that her father was not there. When a morgue official wondered at her fortitude, she replied: "I fear the living, not the dead."14

The carnage without reflected the chaos within. The morgue staff were being stretched to the limit. Neither the storage freezers nor the forensic workers could keep up with the numbers. There was even talk of a plague outbreak. This pressing sense of urgency lay behind the decision to perform so-called "economic autopsies," abbreviated autopsy reports that omitted distinctive characteristics of the bodies that might assist identification at a later date. $^{15}$

And the bodies kept coming, brought in truckloads by cemetery workers, under orders from the new military director of the General Cemetery to "clean up the streets." They found bodies in alleyways, under bridges, washed off the shores of Rio Mapocho: most showing multiple bullet wounds, many shot from the back. Under one bridge alone — the Balamaceda - they found thirty bodies. They re-named the bridge "The Weeping One."16

By the end of the first week, the issue of the permanent disposal of the bodies had reached a crisis. Still, the military authorities were uncertain what course to follow. Early orders to cremate were reversed, and new directives given for secret burials. Patio 29 was a convenient site. Located in the more secluded northern section of the General Cemetery, it had some 320 vacant lots ready for immediate occupancy. ${ }^{17}$

Patio 29 enters the history of the repression in the early morning of September 17, 1973, when truckloads of makeshift coffins began arriving from

11. Zalaquett, Introduction, 4 .

12. Jose Aldunate, s.j., Signos de los Tiempos: Crónicas de una Década en Dictadura (Santiago: LOM Ediciones, 2004).

13. Joan Jara, Víctor Jara, Un Canto Truncado (Madrid: Suma de Letras S.L. 1998) 402-403.

14. Larrain, Patio 29.

15. Maxine Lowy, "How Patio 29 Was Saved from (Total) Disappearance," Human Rights Today, 2006, http://memoriayjustice.cl/english/en_rights-patio.htm. Accesed August 2, 2007.

16. Larrain, Patio 29.

17. Personal interview with Don Rogelio Rodriguez, ex-Inspector General of the General Cemetery, Santiago, Chile, September 22, 2007. 
the morgue. The supply of regular coffins long exhausted, whatever planks of wood lay about had to be hastily assembled into crates, which sometimes collapsed under the strain. Some held two or even three bodies each, depending on their size and the state of their decomposition. Under military watch, cemetery workers unloaded the human cargo into the first four rows of eighty graves, leaving only tin crosses bearing the letters $\mathrm{NN}$ to mark them. ${ }^{18}$

The Patio 29 operation took three months to complete, with a surplus of some thirty bodies buried in nearby Patio 7: the fate of those bodies still a mystery. The job done, the military authorities warned cemetery workers to keep strict silence. But news still filtered through to the families of detaineddisappeared, to the Vicariate and local human rights groups, and to foreign embassies in search of the whereabouts of their nationals. Patio 29 may have been off-limits in terms of exhumation and identification of the bodies, but rumors of what it held — or might hold — increasingly fed into the wider imaginary of the horrorscape that Chile had become. Yet for the families of the detained-disappeared, it was more complex than that. A site of horror, Patio 29 would also become a site of hope. One day it too might yield its awful truths. ${ }^{19}$

The Junta's declared goal to "exterminate the Marxist cancer" assumed an even more sinister form in late 1973, when Pinochet created the DINA— the Department of National Intelligence - which in effect, institutionalized and systematized the horror of the early months of the coup. Its staff was composed of military and civilian agents, many of whom had already participated in the interrogations and tortures in the two stadiums and elsewhere. ${ }^{20}$

The emergence of the DINA went hand-in-hand with the emergence of the policy of "night and fog" which, together with the grey tunics of the Wehrmacht, the military authorities adopted from Nazi Germany. The DINA became the Chilean Gestapo. The Nazi strategy was based on the logic that "intimidation can only be achieved through capital punishments, or through means by which the families of prisoners and the population at large cannot know of their fate." The new policy of extermination injected a new brand of terror and intimidation into the population. House arrests gave way to street detentions to reduce the risk of identification of the military. Now a faceless monster was disposing of their relatives without a trace. ${ }^{21}$

The policy of "night and fog"-extermination by stealth—brought home to the families their condition of utter helplessness. The wife-or is it the widow? - of Dr. Enrique Paris, one of President Allende's close personal advisers, a detained-disappeared since the morning of September 11, recalls:

You have the same sensation described by Kafka. You fight against state terrorism, against giant machinery which has fallen over all your loved ones. And

18. Larrain, Patio 29.

19. Agrupación de Familiares de Detenidos Desaparecidos, "Patio 29: Cementerio General de Santiago," 6-page information leaflet, November 24, 2006, p. 1.

20. Zalaquett, Introduction, p. 3.

21. Ensalaco, Chile Bajo Pinochet, 144-61. 
that all you're morally compelled to do is absolutely worthless. Except as the rescue of a truth that has to remain for others. It produces great anguish. ${ }^{22}$

The emotional legacy of a disappearance, the wife of a detained- disappeared, Sola Sierrra argues, is not accidental: it is intentional. "They wanted to crush the families." ${ }^{23}$ At what point — if any — do families confront the possibility that their missing relatives are dead? Sierra struggles to offer a coherent response.

Yes. No. Look. I can’t think. I know he’s dead. I know that rationally. One thinks rationally that no one can be hidden for so long, as prisoners or anything else. And the tortures we heard about in the hands of the DINA for example, it wasn't possible for any human to resist. All that makes one think rationally that he is dead. But emotionally, until one confronts that situation, 100\%, no, I can't just assume it. Sometimes, when one hears of cases where remains have been recently discovered somewhere, one immediately begins to assume the possibility that the person one was searching for over so many years might be in that gravesite. But when the remains are identified and they don't correspond, one feels a kind of relief. Ah, it wasn't him. It's a devastating situation, because one knows he's dead, but one can't be $100 \%$ sure. I can't say with certainty that I'm a widow. I can't say that. I don't have my husband, that's all. ${ }^{24}$

Meanwhile, the Vicariate of Solidarity continued to gather testimonies and detailed documentation from the families of the detained-disappeared. Based on this evidence, in 1979 its director made public the fact that illegal burials had been conducted in Patio 29, and that people from a known massacre site in Paine - in the outskirts of Santiago-were believed to have been buried there. ${ }^{25}$ Judge Espejo, charged with finding the detained-disappeared of Paine, asked the Vicariate to provide him with relevant set of files. He ordered photographs of Patio 29, constructed a map indicating the location of each of the NN graves, and requested autopsy reports. In the process, he found six cases that coincided with the characteristics of missing people from Paine. He prepared to exhume those graves. ${ }^{26}$ After six years of silence, Patio 29 was once again in the spotlight. What secrets would it yield? And why did Judge Espejo not order a larger inquest? We can only speculate. In 1981 Espejo suddenly declared himself incompetent to carry on the case, and the exercise was abandoned. Before standing down, however, he issued an order not to exhume, cremate, move, or transfer any of the bodies buried in Patio 29. ${ }^{27}$

But the military authorities had other plans. In 1982, as part of Operation Removal of TV sets - a contemptuous code name for the dead bodies-

22. Larrain, Patio 29. Spoken by Maria Eugenia Horvitz, widow/wife of detained-disappeared Dr. Enrique Paris, a member of President Salvador Allende's personal staff.

23. Ensalaco, Chile Bajo Pinochet, 159.

24. Ensalaco, Chile Bajo Pinochet, 160. Extract of interview with Sola Sierra in Santiago, June 1994.

25. n.a., 'Declaran Monumento Nacional al Patio 29', CIREN, Crónica Digital, October 15, 2007, p. 1.

26. Lowy, "How Patio 29 Was Saved," 2.

27. n.a., "Declaran Monumento Nacional." 
some 200 of the 320 bodies were exhumed from Patio 29. An anonymous call from a cemetery worker warned the Vicariate, which made a formal complaint to the Military Prosecutor. ${ }^{28}$ The identities of those bodies, widely as sumed to have been cremated, remain unknown. Patio 29 had been robbed of two-thirds of its detained-disappeared. The remaining would have to wait another nine years before a newly elected democratic government would order their exhumations.

In 1988, a combination of strong international pressure and a growing recognition from within political circles that the time had come to restore Chile to democracy, led Pinochet to agree to a plebiscite in October of that year. Did the Chilean people wish to continue with military rule or not? The answer was a resounding "No" vote. Fourteen months later, in December 1989, Chile had its first free elections in nineteen years. Won by Christian Democrat Patricio Aylwin, leader of the Coalition for Democracy - an uneasy alliance of Centre and Left elements - the so-called transition to democracy had finally been achieved. ${ }^{29}$

But at what price? Just months before Aylwin assumed power, the Military Junta had imposed several restrictions on the civilian government, which guaranteed military responsibility for key institutions. General Pinochet would remain as Commander of the Armed Forces until March 1998, and he would appoint nine members of the Senate with mandates until that date. ${ }^{30}$ The balance of these power-sharing arrangements lay ominously with the military.

In his inaugural speech at the same Estadio Nacional that had been the site of the first mass detentions, tortures, and assassinations of the Pinochet regime, President Aylwin apologized to all the victims and their families on behalf of the Chilean people. He also lay to rest any hopes that the families may have still harbored about their missing loved ones. ${ }^{31}$ It was both a brutal and-most likely — truthful statement. One thing is clear: the rush was on to lay the ghosts - and the demons — of the past to rest. The sooner the question of the whereabouts of the detained-disappeared was settled the better, and Patio 29 would lead the way. But the very nature of the policy of night and fog, and the crime of disappearance, conspired against any quick resolution.

Soon after assuming power, Patricio Aylwin named a National Commission for Truth and Reconciliation. Known as the Rettig Commission, it was charged with gathering information to establish the truth in cases of disappearances, illegal execution, and death resulting from torture carried out by agents of the state between September 11, 1973 and March 11, 1990. In its report a year later, in 1991, it named 979 detained- disappeared and 1319 po-

28. Lowy, "How Patio 29 Was Saved."

29. Amnistía Internacional, "Chile. La Transición en la Encrucijada. Las Violaciones de Derechos Humanos durante el Gobierno de Pinochet Siguen Siendo el Problema Esencial,” March 1996 , p. 3.

30. Amnistía Internacional, "Chile."

31. Gonzalo Vial, "Cada Momento que Pasa es Más Remota la Posibilidad de que los Restos Aparezcan,” El Mercurio, Santiago, April 30, 2006. 
litically executed. ${ }^{32}$ Patio 29 , the most important single finding in relation to the detained-disappeared, again loomed large in the political horizon.

The release of the Rettig Report prompted the Vicariate of Solidarity to issue criminal charges before the courts for alleged illegal burials in Patio 29, with the objective of identifying the remains. In September 1991, a governmentappointed team of anthropologists and forensic doctors began the process of exhumation and identification. But their mandate reflected the strict conditions under which the military had agreed to the operation. This was to be

a "humanitarian process" in which judicial procedures were put at the service of identification of those in Patio 29. But there were to be no penal consequences in solving the issue of the identities of those responsible for the crimes. ${ }^{33}$

It was, as a human rights lawyer and the daughter of a detained- disappeared admitted, the only way of preventing military justice from interfering in or interrupting the process. The compromise suited the government and the immediate needs of the families alike. It also suited the military, which, protected from judicial procedures arising from the findings, could afford to appear conciliatory towards the families. Among many things, Patio 29 had become a site of unusual collaboration between all sides of politics. Everyone had a stake in a successful_-and prompt_-conclusion to the operation.

In 1994, halfway through Operation Patio 29, a third government of the Center-left Coalition parties was elected. Aylwin's successor-Eduardo Frei-inherited the same urgencies to finalize the process of returning the remains of detained-disappeared to their families. Patio 29 was the country's most public open wound. ${ }^{34}$ It fed into the wider debate of an increasingly polarizing society torn between those who would rather forget the past and those committed to a full disclosure of what happened.

The process of exhumation took thirteen days to complete. In the end, only 107 graves were found - and in them, the remains of 126 bodies. A large number of victims were between the ages of twenty and thirty, with a significant number between fourteen and eighteen, and a few between forty and sixty years old. Asked by a reporter what he had to say about the findings - and the fact that two and even three remains had been found in the one tomb, a jovial Augusto Pinochet is said to have replied; “Que economía tan grande!”'Such amazing economy!'35

32. Amnistía Internacional. By 1996, the total figure had grown to 3,107 victims: politically executed and detained-disappeared combined. For the category of detained-disappeared, by 2004, the figure had grown to 1197. With the emergence of new testimonies and evidence, new names have been added to both categories since.

33. Larrain, Patio 29. Spoken by Pamela Pereira, daughter of a Paine detained-disappeared and human rights lawyer.

34. n.a., "Pamela Pereira: Juicios No Se Puden [sic] Cerrar Sin Identificar Restos de Desaparecidos," La Nación, http://www.lanacion.el/prontus_noticias/site/artic/20060422/pags/2006 0422151030.html. April 22, 2006. Accessed August 2, 2007.

35. "El Escándalo del Patio 29: Los Errores de Identificación," http://www.ercilla.cl/web. No 3.293 of May 8-21, 2006. Accessed September 25, 2007. 
The process of identification of the 126 remains varied, from two weeks to two years. Each body was formed anatomically to determine sex, age, height, and special characteristics such as bone or pathologies with systematic bone manifestations, and dental and facial characteristics were examined. ${ }^{36}$ The relatives were keen and active participants throughout the process. Some chose to be present during the exhumation of the remains, and a few recognizedor thought they recognized—-their relative at first glance. "This is my son. I would recognize him anywhere." "I recognized him by his skull. My children inherited the same shape."37 Throughout the sometimes lengthy identification process, staff and families worked closely together. Did your husband tend to lean on one side of the foot or the other when he walked? Can you find one of his shoes? Shared and cherished personal objects and bittersweet memories of personal habits of the disappeared forged bonds of intimacy and trust between them. ${ }^{38}$ Relatives were also asked to provide photographs of faces to superimpose against images of the skull, ideally, with smiles in order to compare tooth with tooth. ${ }^{39}$

The time had come for the families to reclaim their dead.

The act of returning the remains was solemn and traumatic both for the families and the staff of the Medical/Legal Institute. Close relatives were taken to inspect the assembled bones, laid out on a sheet in skeletal form. The staff most closely associated with the identification of the remains then explained in painstaking and painful detail each and every injury detected throughout their investigation: fractured ribs, broken arms and legs, punctured skulls. "This is the trajectory of where the bullet entered and exited his brain." "The lack of any scar tissue suggests he was still alive when they applied a soldering iron to his legs." "Here we see the impact of the bullet that shattered his skull." It was a narrative of horror from which none of the families wished to be spared. For, devastating as it was, it was their narrative: now an integral part of their family history. It was truth at its cruelest: but it was the truth. ${ }^{40}$

The return of the remains also had major practical implications for the families. They could now join the "normal" community of mourners: decide where their loved one would be buried; place a plaque with the name, dates and a loving message; bring flowers and other offerings to the grave. They could have a physical focus for their grief. For the wives of these detained-disappeared, their status changed immediately to that of widow, with considerable legal and financial implications. They were now entitled to compensation, to widows'

36. "Memorias del Grupo de Antropología Forense y Su Aporte al Campo de los Derechos Humanos en Chile," V Congreso Chileno de Antropología, November 8-12, 2004. Simposio: Memoria y Derechos Humanos.

37. Larrain, Patio 29.

38. Caiozzi. Silvio Caiozzi, Fernando Ha Vuelto, Andrea Films Production, 1998. Documentary.

39. Enrique Ahumada, "Dr Patricia Hernández: La Ardua Tarea de Identificar los Cuerpos de Detenidos Desaparecidos," Caso Pinochet, http://www.terra.cl/especial/pinochet-in/entrevista .cfm?num=9. Accessed October 15, 2007.

40. Caiozzi, Fernando Ha Vuelto. 
pensions and their children to health and educational benefits. In social and psychological terms, they could now claim a status that reflected faithfully their circumstances.

Between 1993 and 1998, 96 of the 126 remains had found their final resting place; the rest had to await further developments in identification techniques. Many were buried nearby: some in tombs facing Patio 29, others at the General Cemetery's Memorial Wall of the Detained-Disappeared and Politically Executed erected by President Aylwin in the early period of his administration. A few were flown overseas. ${ }^{41}$ By then, together with excavations of other mass burial sites, the process of finding and identifying the remains of Chile's 1197 detained-disappeared had resulted in the positive identification of 175 . Over a thousand remained missing.

For eight years after the return of the last remains in 1998, Patio 29 remained the centerpiece of the coalition governments' claims that they had done what they could. And for eight years - in some cases ninety-six families of detained-disappeared grappled with the narrative of horror they had heard from the staff of the Medical-Legal Institute. Over those eight years, rituals and patterns of visits to the grave had become part of family life. Some widows had re-married. Parents had died confident in the knowledge that their son's remains now lay safe in the family plot. ${ }^{42}$

Then came the sudden revelations of April 2006: Eight of the 96 remains had been wrongly identified, and the rest were in doubt. ${ }^{43}$ The facts as they stood were devastating enough, but summoned as a group to meet at the headquarters of the Group of the Families of Detained-Disappeared, the families were given no prior warning on what to expect. Once assembled, they were subjected to a power-point presentation in which appeared lists of names under various categories of mistaken identities. It was left to the individual families to search for the name of their loved one on the screen. ${ }^{44}$ The almost casual way in which this devastating information was conveyed to the families only compounded their shock and outrage.

Families who had waited twenty-five years to discover the fate and whereabouts of their father, son, husband, now discovered that the remains they had laid to rest eight, ten, twelve years before did not, or might not, belong to them after all. First the violence of the original disappearance, and now the violence of a second disappearance.

Misidentified means re-opening the wounds, re-starting the search. It means our loved ones have disappeared once again: a pain that we never thought we would live through again. ${ }^{45}$

41. Agrupación de Familiares de Detenidos Desaparecidos.

42. Caiozzi, Fernando Ha Vuelto.

43. Alejandra Chacón, "Patio 29: El Dolor de Verlos Desaparecer Dos Veces," La Nación, April 22, 2006. http://www.lanacion.cl/prontus_noticias/site/artic/20060422/pags/200604022002758 .html. Accessed October 15, 2007.

44. Caoizzi, Fernando Ha Vuelto.

45. "El Escándalo del Patio 29." 
It also meant exhuming and returning the remains, relinquishing widow pension cards, ${ }^{46}$ returning the narratives of torture and murder the families had painfully made their own over time. All these now belonged to someone else's family. But who? From the nightmare of "where are they?" to the nightmare of "who are they?" From state terrorism, to state errorism: what difference had the so-called transition to democracy made to these families of Chile's detained-disappeared?

No sooner had the revelations been made than the recriminations began. The immediate target was the Medical-Legal Institute itself. Pamela Pereira, daughter of a detained-disappeared and human rights lawyer, refused to accept the Institute Director's public apology and demanded his resignation.

Let him go to the church and ask for forgiveness. This is not a matter of forgiveness. This is a question of knowledge and responsibilities. We are not here to commiserate with anybody. ${ }^{47}$

Others, like a leading figure of the Group of Families of Detained-Disappeared, went beyond, accusing successive coalition governments of indifference:

We are living the unimaginable. It is brutal. The human mind cannot comprehend this. We are going through such pain.... There are people responsible for this. Of the dictatorship, we could expect anything because they had snatched from us our loved ones. That was normal within the brutality of the dictatorship. But what outrage that this should happen in these times. This is the post-dictatorship period. We speak of the negligence of the Medical-Legal Institute. But also of the indifference of the authorities who would not listen to us. There are Presidents who would not listen to us-Aylwin, Frei and Lagosbut were prepared to listen to those proposing projects of impunity. ${ }^{48}$

What had gone wrong? Who was to blame? Who knew—and when — that the process had miscarried? What now?

Two obvious targets, the two officers of the Medical-Legal Institute most closely associated with the identification procedures, defended themselves vigorously. At a press conference they exonerated themselves from any blame, arguing they had done "what they could" in the circumstances. ${ }^{49}$ Relations between them and the Group of the Families sank to the level of personal insults. In one interview, the leading forensic medical officer of the Institute suggested that "for some" in the Group it was not convenient for the remains of detained-disappeared to be identified and returned to the families, for it would deprive them of their public profile and forum. ${ }^{50}$

46. "Anticipan Problemas por Error del SML: Viudas Ahora Vuelven a Estar Casadas," Política y Sociedad, La Segunda, Santiago, April 24, 2006, p. 14.

47. J. I. Ortiz, C. Urzua and H. Cossio, "Dramática Notificación a Familiares de DD.DD. por Error del SML: Anuncian Acciones Legales," La Tercera, Santiago, April 22, 2006.

48. Chacón, "Patio 29," p. 2.

49. "Ahora Resulta que No Hubo Error en Patio 29," Crónica. La Cuarta, http://www .lacuarta.cl/diario/2006/05/06/06.02.4a.CRO.PATIO.html, p 2.

50. "Patricia Hernández: 'Lo Digo Abiertamente,"” Política y Sociedad, La Segunda, Santiago, June 13, 2003, p. 26. 
New revelations of government complicity in withholding critical information tore further at the already fragile relations between the state, the Group of Families, and the families themselves. It emerged that as early as 1994, a team of forensic experts from Glasgow University had issued a report to the government on the work-in-progress in Patio 29, urging drastic changes both to the procedures of identification and to the personnel in charge of them. The report had been quietly shelved, and the process of returning the remains to the families allowed to continue. A second report issued by an independent forensic agency in 2003 questioned the professional credentials of the team of experts assigned to Patio 29, and warned that the staff of the Medical-Legal Institute had neither been assessed nor accredited by international forensic organizations. The report urged that any remaining identification procedures, anthropological or DNA, be suspended until the matter was cleared. Again, the recommendations were ignored. ${ }^{51}$

The scandal of Patio 29 — for that is what it began to be called — threatened also to divide the once tightly knit human rights community. The focus of the accusations, some argued, should be not on the errors made by the MedicalLegal Institute, nor even, some dared to suggest, on the remains themselves. Rather, it should be on the failed responsibilities of the state, past and present.

Bones are not a person's most important thing. If there were no Law of Amnesty and the military involved could give us more precise information, we would be much closer to reconciliation. That bodies do not grant, rather the political will to arrive at justice. ${ }^{52}$

It fell to President Michelle Bachelet, heading a fourth successive coalition government, to respond to these charges, and propose a way forward that would restore the government's credibility and reassure the families of a conclusive resolution to the crisis. Time would not be an issue, and resources would not be spared. Soon after, Bachelet assigned a close personal adviser to head a newly appointed team of international forensic experts with wide experiences in sites such as the Twin Towers, Bosnia, Argentina, and Guatemala. ${ }^{53}$ Less than two months after the revelations, Bachelet's government also agreed to declare Patio 29 a national monument. ${ }^{54}$ It reads:

Patio 29

El Patio 29 es un lugar emblemático de las violaciones a los derechos humanos ocurridas entre 1973 y 1990, pues es testimonio del procedimiento llevado a cabo para ocultar los cuerpos y las identidades de los detenidos desaparecidos y ejecutados políticos durante el régimen militar.

51. Javier Rebolledo and Luis Narvaez, "Patio 29: Muertos Sin Nombre,” La Nación, http:// www.lanacion.cl/prontus_noticias/site/aric/20060429/pags/20060429215727.html, pp. 3-4.

52. Ibid., 3 .

53. "Patio 29, en la Hora de las Definiciones," La Nación, p 1. Accessed September 27, 2007.

54. Ministerio de Educación, "Declara Monumento Nacional en la Categoría de Monumento Histórico el Patio No 29," Gobierno Transparente, July 10, 2006. http:/mail.anfitrion.cl/Gobierno Transparente/mineduc/NG/DCTO/2006/08/10463.html. Accessed October, 15, 2007. 
Algunas de las sepulturas de este patio señaladas como NN o Desconocidos fueron el único rastro que permitió a los familiares el hallazgo de los cuerpos; son testimonio de la política de ocultamiento de los crímenes y son, por lo mismo, símbolos de la lucha por la verdad y la justicia para que NUNCA MAS el derecho a la vida sea ultrajado.

Declarado un Monumento Nacional en la categoría de Monumento Histórico en Decreto extento no. 91 del 10 de julio de 2006.

\section{Patio 29}

Patio 29 is an emblematic site of the violations of human rights committed between 1973 and 1990 because it is a testament to the procedures that took place to hide the bodies and the identities of the detained-disappeared and the politically executed during the military regime.

Some of the tombs in this patio marked NN or Unknown were the only trace which allowed the families to discover the bodies; they are a testament to the politics of concealment of the crimes and are, therefore, a symbol of the struggle for truth and justice so that NEVER AGAIN will the right to life be violated.

Declared a National Monument under the category of Historic Monument by Decree No 91 on 10 July 2006.

The transition to democracy was never going to be easy. Reconciling the demands of the families and human rights groups for Truth and Justice with the ever-present threat of another military coup kept successive coalition governments on the defensive. Patio 29 should and could have been the centerpiece of these governments" claims that they had done "what they could." The over thirty-year question of "where are they?" was never going to go away with the closure of Patio 29, but the burden of continuing the search for Chile's detained-disappeared elsewhere in the country would have eased and fallen on future governments, perhaps less hamstrung by the ominous shadow of the military to "forget and move on."

The haste of three successive coalition governments to bring a quick resolution to Patio 29 set the agenda for the series of unfortunate developments that led to the fiasco of 2006 . Key among them were, first, the appointment of a team of forensic experts who, while well-meaning, may not have had the professional training, credentials, and resources for the task entrusted to them; and, secondly, the yet-to-be-explained decisions by the government to ignore the recommendations of two international forensic agencies casting serious doubts on the professionalism of the Medical-Legal Institute and urging that the process of identifications be halted until further notice. Expediency won over care and responsibility.

But to what end? In a post-dictatorship political landscape largely devoid of "good news stories," both the Left and the Right could have rejoiced in what had been achieved in Patio 29. Ninety-six remains had been returned to their families. A warm spirit of co-operation had reigned between the government, the families, and human rights groups. Even the Armed Forces and 
the political Right could claim to have contributed to the spirit of national reconciliation by allowing the exhumations to go ahead: a risky experiment in damage control, particularly in that early period of the transition. Instead, the recent setbacks squandered not only the goodwill of the families and human rights groups, they also scratched the open wound of the detained-disappeared which successive coalition governments had tried so hard to heal. In attempting to reconcile the demands of the Left and the Right, in the end, these governments succeeded only in antagonizing both. And prompting the unthinkable: Patio 29 may be the only political battlefield in Chile where the Armed Forces and the families of the detained-disappeared-in opposite poles of the spectrum in every other conceivable issue of the past thirty-four years-have met in common ground to denounce a common foe.

MaRIVIC Wyndham is a Senior Lecturer in Latin American Studies at the University of Technology Sydney. Her current research interests are centered on post-dictatorship Chile and include the contestation of ex-sites of torture; transitional justice, memory, and trauma; and the politics of memorialization.

Peter Read is an Australian Research Council Professorial Research Fellow in the Department of History, University of Sydney. His interests center on state violence in Australia and Latin America and studies in trauma and national reconciliation. He is currently writing a history of the Aboriginal people of Sydney since the arrival of the British colonizers in 1788. 


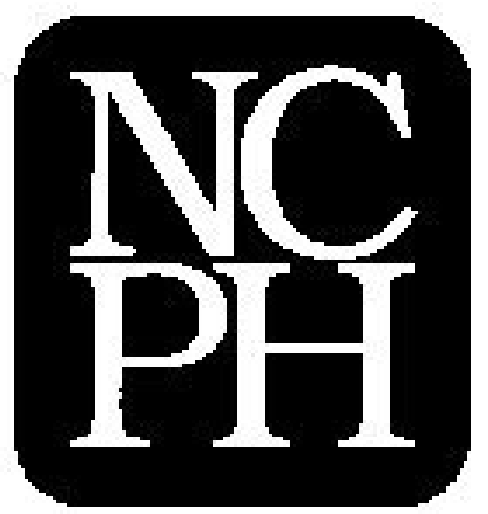

From State Terrorism to State Errorism: Post-Pinochet Chile's Long Search for Truth and Justice

Author(s): Marivic Wyndham and Peter Read

Source: The Public Historian, Vol. 32, No. 1, 〈bold $>$ italic $\rangle$ Where Are the Bodies? A Transnational Examination of State Violence and its Consequences $</$ italic $></$ bold $>$ (Winter 2010), pp. 31-44

Published by: University of California Press on behalf of the National Council on Public History Stable URL: http://www.jstor.org/stable/10.1525/tph.2010.32.1.31

Accessed: 24/02/2011 20:58

Your use of the JSTOR archive indicates your acceptance of JSTOR's Terms and Conditions of Use, available at http://www.jstor.org/page/info/about/policies/terms.jsp. JSTOR's Terms and Conditions of Use provides, in part, that unless you have obtained prior permission, you may not download an entire issue of a journal or multiple copies of articles, and you may use content in the JSTOR archive only for your personal, non-commercial use.

Please contact the publisher regarding any further use of this work. Publisher contact information may be obtained at http://www.jstor.org/action/showPublisher?publisherCode=ucal.

Each copy of any part of a JSTOR transmission must contain the same copyright notice that appears on the screen or printed page of such transmission.

JSTOR is a not-for-profit service that helps scholars, researchers, and students discover, use, and build upon a wide range of content in a trusted digital archive. We use information technology and tools to increase productivity and facilitate new forms of scholarship. For more information about JSTOR, please contact support@jstor.org.

University of California Press and National Council on Public History are collaborating with JSTOR to digitize, preserve and extend access to The Public Historian. 